\title{
Competitive Strategy: As Mediation the Effect of External Business Environment and Total Quality Management Implementation Toward Company Performance
}

(Study at ISO 9000 certified manufacture companies in East Java )

\author{
Kismi Sulistyowati ${ }^{1}$, Ubud Salim ${ }^{2}$, Surachman $^{3}$, Solimun ${ }^{4}$ \\ ${ }^{I}$ (Economics Faculty, Widyagama University, Malang, Indonesia) \\ 2,3,4 (Economics and Business Faculty, Brawijaya University, Malang, Indonesia )
}

\begin{abstract}
This study aimed to test empirically: 1). Effect of external business environment adaptability to company performance. 2). Effect of external business environment adaptability to company performance through competitive strategy mediation. 3). Effect of implementation of Total Quality Management to company performance through competitive strategy mediation. 4). Effect of implementation of Total Quality Management toward company performance. This study uses a contingency approach that integrates external and internal aspects, as well as the important role in determining company's competitive strategy to improve company performance.

The population was 154 units of ISO 9000 certified manufacture companies in East Java. The analysis unit is entire study population (census research) and the respondent is the operations manager. Research data is analyzed by Generalized Structured Component (GSCA).

The findings of empirical study showed: (1). Ability to adapt to external business environment indirectly affect company performance improvement. (2). Adaptability of external business environment affect company performance improvement through competitive strategy mediation. (3). Implementation of Total Quality Management affect company performance improvement through competitive strategy mediation. (4). Implementation of Total Quality Management has indirect effect toward company performance improvement. The research novelty is that competitive strategy is a Completed Mediation between the variable of external business environment adaptation toward company performance and the implementation of Total Quality Management to company performance variables.
\end{abstract}

Keywords: External Business Environment, Total Quality Management Implementation, Competitive Strategy, Company performance.

\section{Introduction}

Indonesia is a country in Southeast Asia that experienced economic growth after the economic crisis of 1997. Manufacture products and services produced are competitive enough and was able to enter global market.

Based on data from global ranking of Competitiveness Report in 2011-2012, which was released by [1], Indonesia's competitiveness ranking has decreased, from 46 in 2010-2011 fall to 48. ASEAN countries (Singapore, Malaysia, Thailand, Indonesia and Philippines) in 2011-2012 has increased. Table 1.1 shows the competitiveness ranking of ASEAN countries as follows:

Table 1.1 Competitiveness Rating of ASEAN Countries [1]

\begin{tabular}{|c|c|c|}
\hline Negara & $\mathbf{2 0 1 0 / 2 0 1 1}$ & $\mathbf{2 0 1 1 / 2 0 1 2}$ \\
\hline Singapore & 3 & 2 \\
\hline Malaysia & 26 & 21 \\
\hline Thailand & 39 & 38 \\
\hline Indonesia & 46 & 48 \\
\hline Philipinnes & 85 & 75 \\
\hline
\end{tabular}

In terms of growth, the manufacture industry in Indonesia, as show $\mathrm{m}$ in Table 1.2, the growth rate of manufacture industries (Non-Oil \& Gas) from 2009 to 2011 fluctuated with average as follows:

Table 1.2 Indonesia Industry Manufacture Growth [2]

\begin{tabular}{|c|l|c|c|c|}
\hline No. & Industry Subsector & $\mathbf{2 0 0 9}(\boldsymbol{\%})$ & $\mathbf{2 0 1 0}(\boldsymbol{\%})$ & $\mathbf{2 0 1 1}(\boldsymbol{\%})$ \\
\hline 1 & Food, Beverage, Tobacco & 11,2 & 2,73 & 5,39 \\
\hline 2 & Textile, Leather, Footwear & 0,6 & 1,74 & 0,38 \\
\hline 3 & Wood and forest goods & $-1,38$ & $-3,50$ & $-2,02$ \\
\hline
\end{tabular}




\begin{tabular}{|c|l|c|c|c|}
\hline 4 & Paper and prints & 6,4 & 1,64 & 1,81 \\
\hline 5 & Chemical fertilizers, rubber goods & 1,64 & 4,67 & 4,44 \\
\hline 6 & cement, non-metallic minerals items & $-0,51$ & 2,16 & 3,07 \\
\hline 7 & base metals, iron, steel & $-4,26$ & 2,56 & 2,80 \\
\hline 8 & Conveyance, machinery, equipment & $-2,87$ & 10,35 & 10,79 \\
\hline 9 & Other goods & 3,19 & 2,98 & 3,09 \\
\hline 10 & Mean manufacture processing industries & $\mathbf{2 , 5 6}$ & $\mathbf{5 , 0 9}$ & $\mathbf{5 , 5 6}$ \\
\hline
\end{tabular}

Table 1.1 and Table 1.2 gives an overview of manufacture industry in Indonesia has decreased despite the competitiveness, but from 2009 to 2011 the manufacture industry has increased significantly. This reflects the ability to meet the goods demand, both national and international markets.

East Java province has major contribution to economic growth in Indonesia. The export value of East Java, as the impact of financial crisis that occurred in 1997, declined sharply in 1999 and 2002. From 2003 through 2008, the export value of these products in East Java began to increase although still lower than previous years. Based on a regional scale, the development of export value in East Java over last 10 years has increased. In 2009 to 2011, the export value of East Java showed higner trend. These conditions provide opportunities for ISO 9000 certified manufacture companies in East Java to create a product to compete amid a turbulent external business environment.

\section{Research Gap 1:}

Some theoretical studies indicate the importance of relationship between business environment with external company performance $[3,4]$. The results of empirical studies $[5,6,7]$ that external business environment has significant effect toward company performance and company's business strategy is not major factor for company performance [8]. External business environment negatively affect company performance. It indicates inconsistency between the empirical results on theory.

It is a research development to measure the capability of ISO 9000 certified manufacture companies in East Java in adapting to external business environment and its impact toward company performance improvement through competitive strategy mediation.

\section{Research Gap 2:}

Total Quality Management (TQM) is a recent breakthrough in management which all activities aimed to optimize customer satisfaction through sustainable process improvement. TQM is a thorough activity of quality management activities: $[9,10,11]$

Some empirical studies demonstrate the importance of relationship between TQM implementation with company performance. [11,12,13,14,15,7]. Research [16.14] shows that TQM practice does not have a positive relationship with company performance, but only operational performance. This shows an inconsistency between the empirical results and theory.

This study explores the empirical results of previous studies and to obtain answers the mediating role of competitive strategy between external business environment and TQM implementation toward company performance of ISO 9000 certified manufacture companies in East Java. This study examine weather the mediating role of competitive strategy are : 1). Complete Mediation or 2). Partial mediation or 3). Non mediation.

It is research development to measure capability of ISO 9000 certified manufacture companies in East Java in implementing Total Quality Management (TQM) and its effect to improve company performance through competitive strategy mediation.

\section{Research Questions:}

1. Is competitive strategy acts as a mediating variable the effect of external business environment adaptation toward company performance.

2. Is competitive strategy acts as a mediating the effect of Total Quality Management Implementation toward company performance.

The problem formulation are follows:

1. Is ability to adapt to external business environment significantly affect company performance of ISO 9000 certified manufacture companies in East Java?

2. Is ability to adapt to external business environment through competitive strategy mediation significantly affect company performance of ISO 9000 certified manufacture companies in East Java?

3. Is implementation of Total Quality Management through competitive strategy mediation has significant effect toward company performance of ISO 9000 certified manufacture companies in East Java? 
4. Is Total Quality Management implementation has significant effect toward company performance of ISO 9000 certified manufacture companies in East Java?

\section{Theoretical review / Literature Review}

2.1. External Business Environment: Company external environment divided into two main areas, namely the general environment or the macro-environment and industry environment [3]. Macro environment are elements within wider community that may affect performance of business or existing companies. Included in the macroenvironment are: economic force, socio-cultural force, technological force, political/legal, and demographic. Macro environment also can not be directly controlled by company.

Industrial/ business environment performance are factors that directly affect company. It affect significantly affect affect significantly new entrants, power of suppliers, power of buyers, substitute products, and intensity of rivalry. While the environment indirectly affect organization or company.

2.2 Total Quality Management: The opinions above show clearly that TQM is an activity aimed to meet customer expectations through continuous improvement. The goal is to improve organization to eliminate waste, simplify the process and focuses on the usage of quality practices that will ultimately affect every management activity, thus customer satisfaction is achieved and company can achieve a competitive advantage.

TQM is a special program for each company formed with some key elements, namely [11]:

1. Customer focus

2. Strategic planning

3. Continuous improvement.

2.3. Competitive Strategy: There are three competitive advantage strategies or generic strategies within company, which is $[17,18,19]$ :

1. Cost-Leadership Strategy or Cost-minimization strategy

2. Differentiation or innovation strategy

3. Focus or Imitation strategy

The company success is determined by company ability to integrate its internal capabilities with the opportunities from external environment.

2.4. Company performance : Performance measurement is complex and a major challenge for researchers because as a construct, performance is multi-dimensional and therefore measurements using only single dimension is not able to provide a comprehensive understanding [20.6]. Performance measurement should use or integrate various measurement dimensions (multiple measure) [3]. In the Balanced Scorecard, company performance is measured by four perspectives: financial, customer, internal business and growth and learning perspective [23]. There are four indicators on company performance variable, namely: (1). financial, (2). customer, (3). internal business process, and (4). Learning and growth perspective.

\subsection{Conceptual Framework for Research}

\section{Conceptual Framework and Research Hypotheses}

The conceptual framework developed in this study based on the theoretical study and results of previous studies to evaluate external business environment, TQM implementation, competitive strategy and its affect toward company performance of ISO 9000 certified manufacture companies in East Java. 


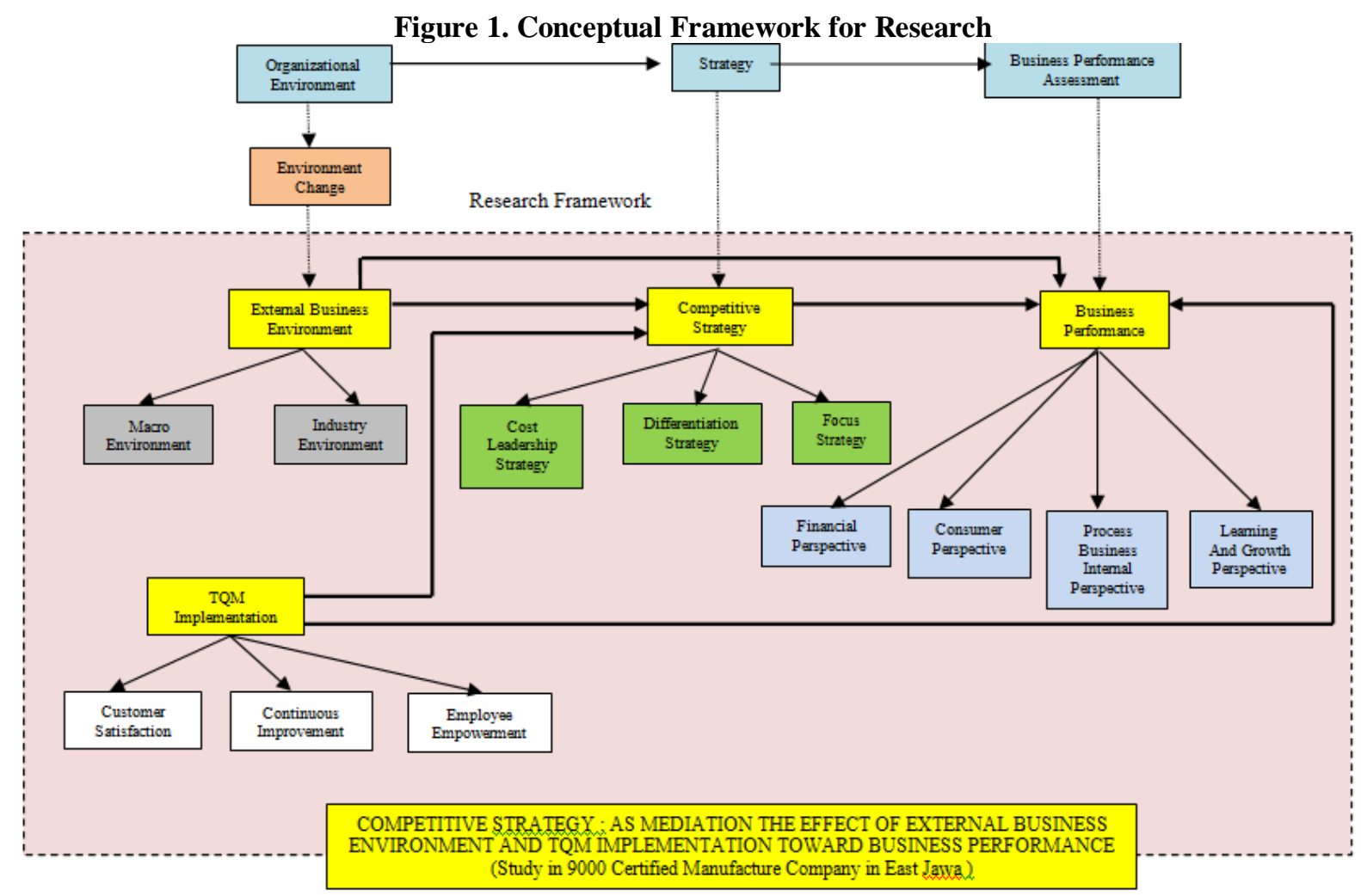

\subsection{Research Hypothesis}

H1: The ability to adapt to external business environment, will improve company performance of ISO 9000 certified manufacture companies in East Java.

H2: The ability to adapt to external business environment through the mediation of accuracy in determining the competitive strategy will improve company performance of ISO 9000 certified manufacture companies in East Java.

H3: The ability of Total Quality Management (TQM) Implementation through mediation the accuracy in determining the competitive strategy will improve company performance of ISO 9000 certified manufacture companies in East Java.

H4: The ability of Total Quality Management (TQM) implementation will improve company performance of ISO 9000 certified manufacture companies in East Java.

\section{Figure 2. Empirical Research Model}

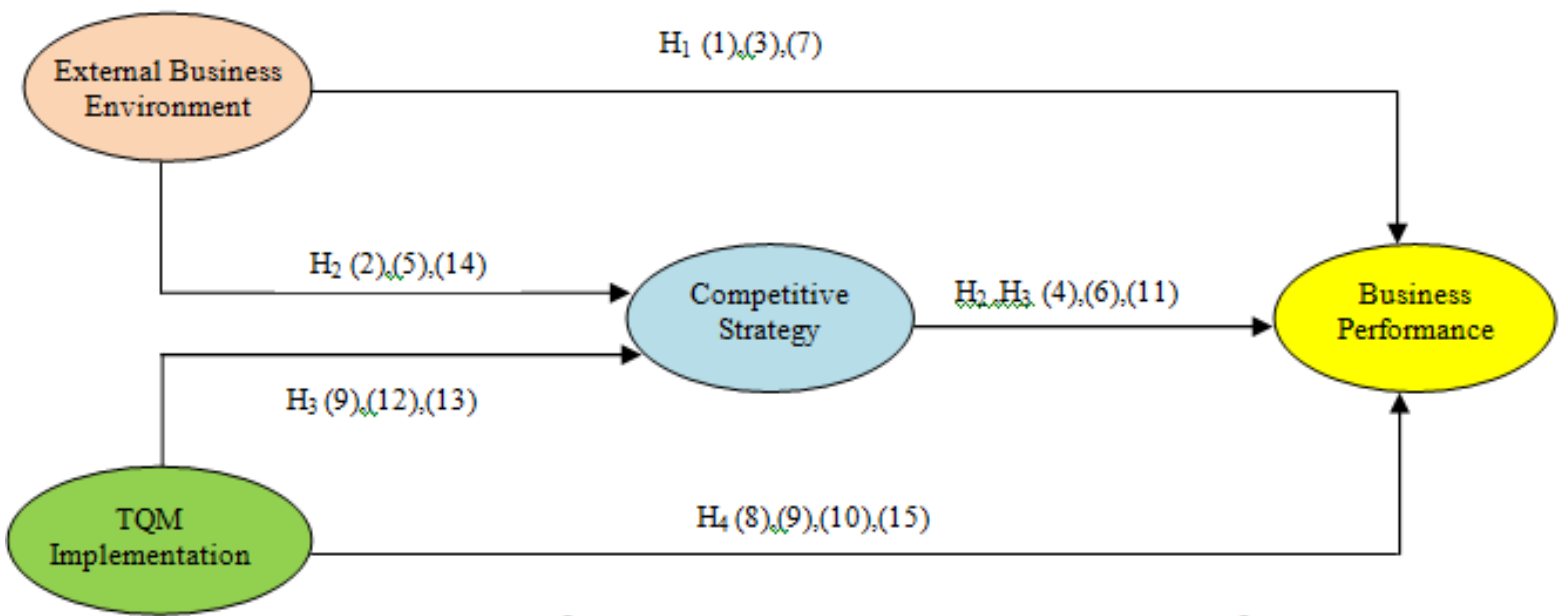

References: $[6,37,38,31,41,39,8,5,12,13,14,34,16,42,43,9]$ 


\section{Research Methodology}

\subsection{Population Research}

The study population was all 154 manufacture company that has been certified ISO 9000 in East Java. Considerations to select population is ISO 9000 certified Company provides an opportunity for export as well as able to survive in globalization era. The ISO 9000 usage in developed countries from time to time grow more rapidly. This shows that the international recognition of product quality is important for company, but this does not apply to the RRC State.

This condition prove an performance increase for firms that adopt the philosophy and obtained ISO 9000 certificate. Japan is a country with $80 \%$ growth per year, followed by Germany $78 \%$, Canada $77 \%$, USA $72.8 \%$, India 72\%, Malaysia 63\%, France 53.2\%, Singapore 53\%, Australia and New Zealand $41.6 \%$ [21].

Data was collected through questionnaire research instruments sended by mail and in person. Respondents in this study is the operations manager or quality control manager from all analysis unit, because manager responsible for company's operations. Production / operations manager or quality control manager selected because they know and responsible for the production and operations in company [22].

\subsection{Variable Measurement Techniques}

Variable measurement techniques used in this study can be described below. Respondents were asked to provide responses to each item, and each item was assessed by a Likert scale assessment with intervals score : 1 (strongly disagree), 2 (disagree), 3 (Neutral), 4 (agree) and 5 (strongly agree).

\subsection{Data Analysis Method}

\subsubsection{Descriptive Statistics Method}

Descriptive statistics is used to provide an overview the demographics of survey respondents, as well as a description of research variables without generalizing.

\subsubsection{Inferential Statistical Methods}

The inferential statistics is used to test the hypothesis in a study. Hypothesis test in this study using the analysis tool of Generalized Structured Component Analysis (GSCA) [27].

\subsubsection{Mediation Variables Test}

This study use analysis of Generalized Structured Component Analysis (GSCA) to determine the effect of mediating variables with approach of examining the coefficient differences [27].

The result of mediating variables are follows:

a. Completed Mediation.

b. Partial Mediation.

c. Non Mediation. [27]

\subsection{Overview of research object}

\section{Research Findings and Discussion}

The research object is entire 154 of ISO 9000 certified manufacture companies in East Java. It consists of 20 groups of commodities, including: food and beverage industry, cement, textiles, cigarettes, ceramics, plastics, machinery, wood, paper, glass, metals, cables, apparel, chemicals, bottled water, household goods, electronic, pharmaceutical, automotive and others. The research location is in East Java, include: Surabaya, Gresik, Sidoarjo, Pasuruan, Malang and others

Table 5.1 Object Data research [2]

\begin{tabular}{|l|c|c|}
\hline No & City & Total \\
\hline 1 & Surabaya & 35 \\
\hline 2 & Gresik & 16 \\
\hline 3 & Sidoarjo & 15 \\
\hline 4 & Pasuruan & 30 \\
\hline 5 & Malang & 6 \\
\hline 6 & Lain-lain & 5 \\
\hline & Grand Total & 154 \\
\hline
\end{tabular}

\subsection{Validity and Reliability Test of Research Instruments}

Before spreading research instruments to analysis unit, it conducted a randomized trial to 30 respondents. The test results of research instrument validity and reliability with 39 items and 4 variables are 
valid and reliable. These results indicate that the research instruments (questionnaires) can be distributed to the research object of ISO 9000 certified manufacture companies in East Java as the analysis unit.

\subsection{Research Model Conformity Assessment (Goodness of Fit)}

Suitability test of research model (Goodness of Fit) is ran before testing the research hypothesis. It uses Generalized Structured Component Analysis (GSCA).

Table 5.2 Model Fit Result Using GSCA

\begin{tabular}{|c|c|}
\hline \multicolumn{2}{|c|}{ Model Fit } \\
\hline FIT & 0.565 \\
\hline AFIT & 0.552 \\
\hline GFI & 0.974 \\
\hline SRMR & 0.097 \\
\hline NPAR & 29 \\
\hline
\end{tabular}

Sources: Processed Data (2011)

Table 5.2 shows the FIT values obtained is 0.565 . It can be interpreted that the model formed is good (fit). That is, external business environment, TQM implementation, competitive strategy and company performance can be explained by the model about 0.565 , while the remaining 0.435 can be explained by other variables outside of these variables in this study. GFI (goodness of Fit Index) is 0.974 (close to 1), it is good. This shows that the model can explain the diversity of data used in the study. SRMR (Standardized Root mean Square Residual) is 0.097 (close to 0), it is good. It can be explained that the model is appropriate, it is a value that used to measure the deviation of parameters value in the model study.

\subsection{GSCA Analysis Results}

This study to test or examining mediation variable with Generalized Structured Component Analysis (GSCA), coefficient differences approach, using two analyzes: analysis that involving mediation and non mediation variable.

The result of mediation variables can be categorized as follows:

a. Completed Mediation.

b. Partial Mediation.

c. Non Mediation. [27]

\subsubsection{Mediation Analysis between External Business Environment and Company performance}

Figure 5.1 shows model analysis results with competitive strategies as mediation variable, where:

a. Path coefficient of external business environment toward competitive strategy (mediating variable) is $0.214^{*}$, significant.

b. Path coefficient of competitive strategy (mediating variable) toward company performance (dependent variables) is $0.345^{*}$, significant.

c. Path coefficient analysis of external business environment (independent variables) toward company performance (dependent variables) are controlled by the competitive strategy variables (mediating variables) of 0.057 , insignificant.

Test results prove that the competitive strategy is mediating variable between external business environment and company performance, and it is a Completed Mediation.

\subsubsection{Mediation Analysis between TQM Implementation toward Company performance}

Examination be done using the coefficient difference (figure 5.1) and it shows following results:

a. Path coefficients of TQM implementation toward competitive strategy (mediating variables) is $0.565 *$, significant.

b. Path coefficient of competitive strategy (mediating variable) toward company performance (dependent variables) is $0.345^{*}$, significant

c. Path coefficient of TQM implementation (independent variables) toward company performance (dependent variables) are controlled by competitive strategy (mediating variables) of 0.074 , insignificant.

Test results prove that the competitive strategy variables are mediating variable between TQM implementation and company performance, and Completed Mediation. 
Figure 3. Diagram for hypothesis testing and path coefficient for GSCA

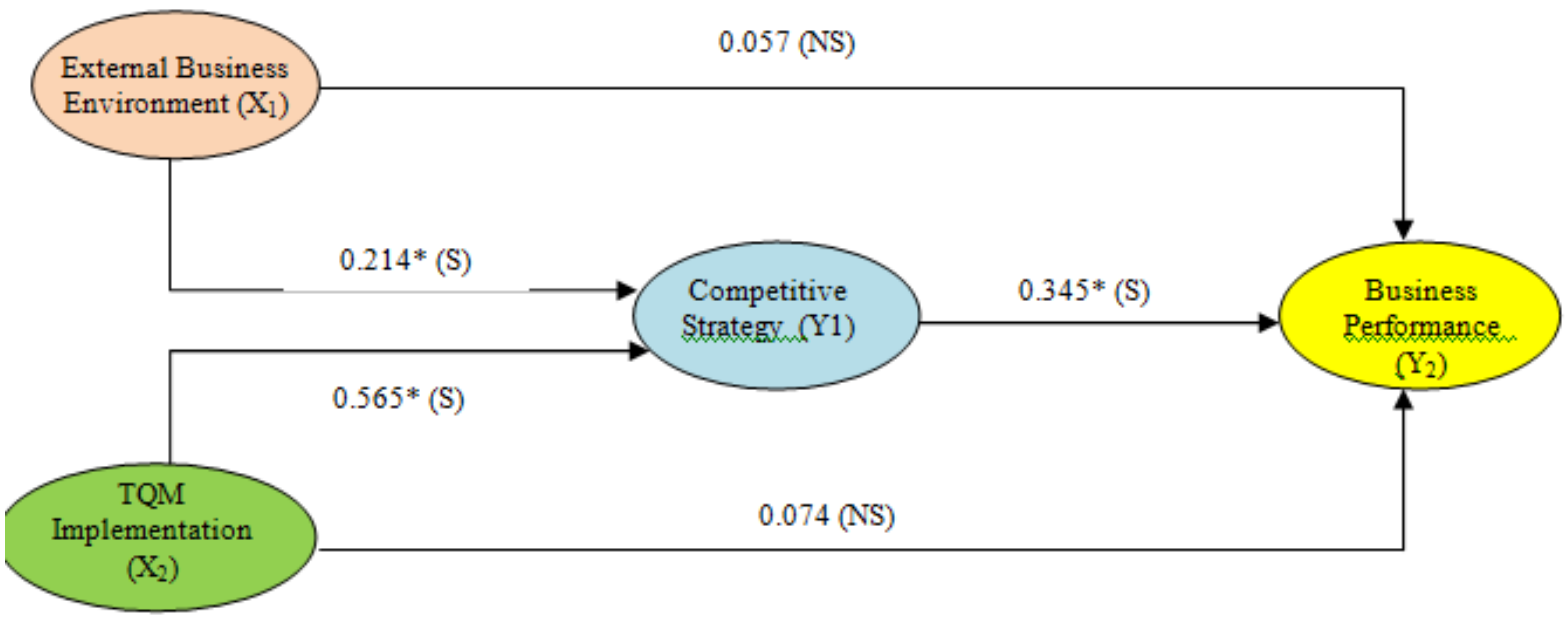

Note $: \mathrm{S}=$ Significant $; \mathrm{NS}=\mathrm{Non}-$ Significant

\subsection{Hypothesis Testing}

\subsubsection{Testing Hypothesis 1}

The effort ability of ISO 9000 certified manufacture companies in East Java to adapt and align with external environment has a positive relationship toward company performance. It is shown with a positive path coefficient value of 0.057 , but not significantly at $95 \%$ confidence level. This means that the adaptation of external business environment with the uncertainty affect company performance insignificantly.

These results support the findings of research conducted by the [29.8] where external business environment does not affect performance of business directly but through the mediation strategy. The findings in this study are consistent with contingency theory that the alignment of business strategy with external environment will determine the viability and company performance [30.31].

Therefore, hypothesis 1 (H1) in this study was rejected or failed to be accepted as true.

\subsubsection{Testing Hypothesis 2}

Ability effort of ISO 9000 certified manufacturing company in East Java to adapt and align with the external environment has a positive and significant relationship toward company performance through the selection accuracy of competitive strategy. This is shown on a positive path coefficient value of $0,214 *$ and significant with $95 \%$ confidence level. This means that the external business environment directly affects the competitive strategy selection, or the company's ability to adapt to the external business environment will influence the accuracy of competitive strategy selection.

Support from the test results showed that competitive strategy as mediating variables proved to mediate the external business environment variables with company performance. It is a Complete Mediation, the competitive strategy is the mediating variable to improve company's company performance.

The test results were consistent with the hypothesis [32] which says that the preparation of company's strategy should be based on the analysis and diagnosis of internal resources and external environment synergycally are must be input in the preparation of company's strategy to achieve company performance.

Therefore, hypothesis $2(\mathrm{H} 2)$ is accepted or can be verified.

\subsubsection{Testing Hypothesis 3}

From the data analysis, the creating products according to customer needs, continuous improvement and employee empowerment will improve company's competitive strategy. It is evident from the path coefficients the effect of TQM implementation toward competitive strategy is significant positive of 0.565 with 95\% confidence level. This means that TQM implementation directly affect company's competitive strategy, or indicate that TQM implementation is a part in determining company's competitive strategy.

The above results clearly show that TQM implementation is an activity aimed to meets customer expectations through continuous improvement. The goal is to improve company's operations to eliminate waste, simplify the process and focuses on the use of quality practices that will ultimately affect every management activity. Therefore, customer satisfaction is achieved and company can achieve a competitive advantage [31].

These results meant that by implementing TQM properly will be able to contribute or affect competitive strategy selection to improve company performance. The test results show that the mediating variable mediation of competitive strategy is complete, or TQM implementation in creating product orient to 
customer satisfaction, continuous improvement and employee empowerment and engagement strategies become an effort to create a quality product as well as having high competitiveness. It will be able to be an effort to improve company performance of ISO 9000 certified manufacture companies in East Java.

Thus, hypothesis $3(\mathrm{H} 3)$ received or verified.

\subsubsection{Testing Hypothesis 4}

Data analysis result in this study related with products production according to customer needs, continuous improvement and employee empowerment will be able to increase company performance, it is shown by path coefficient the effect TQM implementation toward company performance of 0.074 , positive but not significant at 95\% confidence level. This means that TQM implementation conducted by ISO 9000 certified manufacture companies in East Java is positif but insignificant to increase company performance. It also does not shows indication that the TQM implementation will directly improve company performance. Mediation test results indicate that the ability to implement TQM in creating the product is not able to improve company performance of ISO 9000 certified manufacture companies in East Java except it mediated by the accuracy in determining the competitive strategy.

These results are consistent with previous empirical studies [16.12].

Thus, hypothesis 4 (H4) in this study is rejected or failed to be accepted as true.

\subsection{Research Findings Discussion}

\subsubsection{External Business Environment Affect toward company performance.}

The theory suggests that each company is expected to have ability to adapt with external business environment as an opportunity and a challenge. In addition, company should have ability to manage internal business environment as strengths and weaknesses in order to achieve the goal to improve company performance $[4,34,35]$. The results of analysis GSCA indicate that the external business environment does not significantly affect company performance of ISO 9000 certified manufacture companies in East Java. This gives a sense that ability to adapt to external business environment does not directly affect toward company performance improvement. The description analysis about external business environment adaptation to macro environment gives result that technological change is an company option at this time. Today, technology development progress very rapidly, both in business and in support business activities. Any business that continuously to keep abreast in technological developments can applied them to products or services produced or on operation mode. Technological change can affect many elements in society [3]. With the rapid technological change, it is important for companies to learn the technology segment quickly and thoroughly. These elements include technology segment regarding product innovation, and new communication technologies. It could to say the importance of this effort is shown by the finding that companies that adopt new technology earlier often achieve a higher market share and generate higher profits.

Adaptation to environment industry to improve company performance, according to respondents perceptions, is a condition that affects performance improvement efforts, supplier bargaining power. Suppliers can use the bargaining power or affect the performance of company buyer by raising prices or lowering the quality of goods or services are sold as inputs for the manufacture industry.

These results reinforce the results of an empirical study [8.6] that external business environment did not have an impact toward company performance or business growth level.

But the results are not consistent with empirical results [5.29, 37] which says that external business environment directly affects company performance.

\subsubsection{External Business Environment effect toward company performance Mediated by Competitive Strategy}

Environmental factors are external and internal factors that can affect the formulation and company control strategy. The success of a company is determined by company ability to integrate its internal capabilities with the opportunities of external environment to determine the competitive strategy. There are three strategies of competitive advantage or generic strategies within company, namely: 1. Cost-leadership Strategy 2. Differentiation or innovation strategy 3 . Focus or Imitation strategy [4]. [17,18,19].

Results showed the highest mean of data description of respondents perception with a generic strategy is cost leadership strategy that executed by production cost efficiency. This option indicates that the strategy to develop production costs efficiency will have an impact in determining the cost and profit. Differentiation strategy shows the highest rates in creating varied and high-value products. This suggests that differentiation strategy of the company is an effort to create competitive products where the products are more varied and have more value than competing products. Companies choose focus strategy by creating products that match customer expectations, able to provide satisfaction and will create repeat purchases. 
Based on hypotheses test results by GSCA analysis, it shows that the biggest factor loading of competitive strategy is differentiation strategy. It means that the differentiation strategy is a strategy that is able to compete as an option strategy for company. These results are in line with company based on average respondent perception that a differentiation strategy currently implemented by company in an effort to improve their company performance. The analysis results also show that the ability to adapt to external business environment has indirect effect (not significant) toward company performance improvement. Efforts to improve company performance be done through competitive strategy mediation. Test result with GSCA suggests that competitive strategy is complete mediation between the ability to adapt to external business environment and company performance.

Important understanding for ISO 9000 certified manufacture companies in East Java is the study findings suggest that adaptation business environment has a significant role in determining competitive strategy selection as mediation in effort to improve company performance.

The study findings is consistent with some other research results or empirical studies earlier [38, $31,39,40,41,8,7]$, that the alignment between the strategy and external environment affects better performance. Another study suggests that organization/company crisis happened if they do not create alignment between strategy with external environment [42]. Similarly, the preparation of company strategy should be based on analysis and diagnosis of internal resources and external environment that synergically must become input in corporate strategy formulation $[3,32]$.

Based on the analysis, this study provides findings that the ability to adapt with external business environment plays a significant role in determining competitive strategy as mediation in an effort to improve company performance for ISO 9000 certified manufacture companies in East Java.

\subsubsection{Effect of TQM Implementation toward company performance mediated by Competitive Strategy}

TQM has three basic philosophy that can be drawn as a meet point of different opinions about TQM and its implementation. Then, it is then used in this study as an indicator of TQM implementation variable [9.11]. Three basic philosophy as an indicator of TQM implementation are as follows: 1. Focusing on customer satisfaction (Customer Focus). 2. Increase quality continuously (Continuous Improvement). 3. Empowerment and involvement of employees (Employee Empowerment and Involvement).

Mean test result of respondent perceptions of TQM implementation toward customer satisfaction aspects shows that in creating products company always adjust to customer needs. From the aspect of continuous improvement, based on respondent perceptions, in creating products the company continues to make improvements in the product, the product must maintained in excellent quality. Aspects of employee empowerment and involvement in producing superior products, as perceived by the respondents, is to maintain a harmonious relationship of organization members, as well as the aspirations and participation of employees in the work. Findings based of respondents perception indicated that employees role to create a quality product in accordance with customer expectations. ISO 9000 certified manufacture companies in East Java implement TQM with continuous process production process improvement and harmonization the relations between organization members.

The study result using GSCA analysis on TQM implementation shows that customer satisfaction has a loading orientation biggest factor. This indicates that creating competitive product will able to give satisfaction to the customer and the customer will make repeat purchases. Results shows that TQM implementation does not have significant effect toward company performance. This means the ability to implement TQM does not directly affect toward company performance improvement.

TQM implementation has positive and significant effect on competitive strategy. These results meant that by implementing TQM properly will be able to contribute to company performance improvement through competitive strategy mediation. The competitive strategy is complete mediation. It meant that in order to improve company performance, ISO 9000 certified manufacture companies in East Java is not enough to implement TQM only, but TQM implementation must be mediated by strategy to improve company performance.

TQM implementation in ISO 9000 certified manufacture companies in East Java show that creating a product orient to customer satisfaction is the strongest indicator, and strengthened by empowerment and engaging employees to create innovative and high quality products with competitive strategy become input to improve company performance in the face of free trade era.

\subsubsection{Effect of TQM implementation toward company performance}

The study findings of average respondents perception show that creating products orient to customer satisfaction with meeting customer needs, make continuous improvements in the manufacture process to establish and maintain relationships harmonization members are important to improve company performance. 
GSCA analysis results indicate that the implementation of TQM oriented customer satisfaction when creating a product is the strongest indicator, this reflected by greatest factor loading values. These results reflect compliance with average respondents perception. In creating the product, ISO 9000 certified manufacturing company in East Java concern to customer satisfaction. The findings also indicate that the effects of TQM implementation on business performance is not significant. This indicates that TQM implementation has indirect effect toward business performance improvement. This condition indicates that the TQM implementation does not provide direct support to improve business performance. TQM Implementation has always done by ISO 9000 certified manufacture company in East Java, in an effort to improve their business performance through competitive strategy mediation. The research findings indicate that competitive strategy mediation is a complete mediation between TQM implementation and business performance.

Good quality products will create customer loyalty (customer's future return), reduce customer complaints as well as create zero defect, thereby increasing the profitability and market share of the company, and ultimately improve business performance.

These results are consistent with findings [14] that there are positive effects of TQM implementation on operational performance, employee relations, and customer satisfaction, but TQM implementation can not guarantee the performance, innovation and new product development with superior profitability. These results are also in line with empirical studies conducted by $[43,7]$ that holistic/comprehensive implementation TQM contribute to improve performance. Another study by [43] found that the TQM implementation is predictor of organizational performance and managerial competencies moderate the TQM implementation and organizational performance.

\subsection{Research Findings}

From hypothesis results testing and discussion, the findings of study are as follows:

1. The good ability to adapt to external business environment does not directly affect the effort to improve company performance, but must through competitive strategy mediation.

2. The good ability to implement TQM not directly affect businesses in effort to improve company performance, but must through competitive strategy mediation.

3. Competitive strategy is a perfect mediation in effort to improve company performance with mediate external business environment and TQM implementation toward company performance.

4. Competitive strategy chosen by ISO 9000 certified manufacture companies in East Java as an effort to improve company performance is product differentiation strategy to create a distinctive, provide specialized services and provide after sales service to customers.

5. Business performance with the Balanced Scorecard concept suggests that the customer perspective is a priority in measuring company performance as well as a financial perspective.

\section{Conclusion}

Data analysis and discussion of this study examines competitive strategy as a mediation the affect of external business environment and the Total Quality Management implementation toward company performance of ISO 9000 certified manufacture companies in East Java. The Conclusions can be presented as follows:

1. The better a company's ability to adapt to external business environment, consisting of macro environment factors, especially technological change and inflation and industrial environments, especially in the bargaining power of suppliers and bargaining power of buyers, it does noet provides direct impact on efforts to improve company performance at ISO 9000 certified manufacture companies in East Java.

2. Company's ability to adapt to external business environment, the macro environment, technological change and inflation, when the industry, bargaining power of suppliers is a priority factor in the effort to adapt external business environment become input in determining competitive strategy. Competitive strategy is perfect mediation between the ability to adapt with external business environment in order to improve company performance at ISO 9000 certified manufacture companies in East Java.

3. Company's ability to implement TQM in creating products that match with customer expectations is an input to accuracy in selecting competitive strategy. It is mediation the effort to improve company performance of ISO 9000 certified manufacture companies in East Java. Differentiation strategy is identified as a competitive strategy chosen company by creating varied products, the product is worth more and provide distinctive services. This is a competitive strategy chosen by ISO 9000 certified manufacture companies in East Java, in order to improve company performance.

4. Company's ability to implement TQM in creating products that have a competitive edge is always oriented to customer satisfaction, make continue improvement, employee empowerment, and maintain 
harmony relationship between the organization members, but did not give a direct effect to company performance improvement of ISO 9000 certified manufacture companies in East Java.

\section{Suggestion}

From the results obtained of this study, some suggestions can be presented as follows:

1. Business environment development, TQM implementation, competitive strategy and company performance are a research development in strategic management field.

2. To generate competitiveness (competitive advantage) to compete, ISO 9000 certified manufacture companies in East Java should be able to align the competitive strategy with external business environment as well as the innovation and continuous improvement of product produced to meet the customer need.

3. Company give training to employees, improve product quality, provide distinctive services and foster harmony relationship between the members of company in order to provide a positive impact toward company performance.

4. Government gives SMEs an opportunity to obtain ISO 9000 certificate in order able to compete at national and international levels.

5. ISO 9000 Certificate can be used as a reference to make standardization certification of industrial products in the country, which will have high competitiveness, as well as having the ability to tap into global market.

6. This research use the analysis unit of ISO 9000 certified manufacture companies in East Java, is recommended the future research conducted on a larger area.

\section{Research Limitations}

1. The object of this study is ISO 9000 certified manufacture companies in East Java. Therefore, the results can not be generalized for manufacture companies in Indonesia.

2. ISO 9000 certified manufacture companies in East Java less open and low willingness to accept the researchers that affect to data collection required.

3. Data collection by mail-survey and directly with the help from field researcher shows a different response from the analysis unit so it the result less than maximum results.

[1] World Economic Forum 2011-2012

\section{References}

[2] Biro Pusat Statistik , 2011 Jawa Timur

[3] Hitt,Michael A. R, Duane Ireland and Robert E.Hoskisson.2001. Manajemen Strategis, Daya saing dan Globalisasi, Buku 1, Jakarta. Penerbit Salemba Empat.

[4] Pearce John. A \& Robinson, Richard B Jr, 2004. Strategic management Formulation, Implementation and Control. Fifty Edition. Illinois. Burr Ridge.

[5] Adnan Hakim, 2007. Karakteristik kewiurausahaan, lingkungan bisnis dan kapabilitas organisasi :Pengaruhnya terhadap strategi bisnis dan kinerja Usaha.Disertasi UB Malang

[6] Beal, Reginald, M. 2000. Competing Effectively: Environmental Scanning. Competitive Strategy. And Organizational Performance Hi Small Manufacturing Firms. Journal of Small Business Management. Vol. 22. Pp. 27-45.

[7] Gunarianto, 2005. Pengaruh Strategi Keunggulan Bersaing, TQM, Cost Quality, Sistem Akuntansi terhadap Kinerja Perusahaan Manufaktur. Disertasi Program Pascasarjana UNPAD Bandung.

[8] Yurniwati. (2003). Pengaruh Lingkungan Bisnis Eksternal dan Perencanaan Strategik Terhadap Kinerja Perusahaan Manufaktur. Disertasi. Pascasarjana UNPAD. Bandung.

[9] Krawjesky,L.J.,\& Ritzman,L.P., 2002. Operation Management : Strategy and Analysis. Sixth Edition, Prentice Hall International, Inc.

[10] Dessler, Garry. 2003. Human Resource Management. New Jersey: Prentice Hall Inc.

[11] Tenner, Arthur R and Detoro Irving, J (1993), Total Quality Management. Adison Wesley Publishing Company, USA.

[12] Veeri Arumugam, Keng-Boon Ooi, Tuck-Che Fong ,2008,.’TQM practices and Quality Management Performance. International Journal of Quality \& Reliability Management.

[13] Daniel L. prayogo, Soon W Hong. 2008. The Effect of TQM on Performance in R\&D environment : A Perpective from South Korean Firms. Journal of Quality Management 167-189.

[14] Terziovski, M. \& Samson, D., 1999, The link between Total Quality Management practice and Organizational performance International Journal of Quality \& Reliability Management. Vol.16 No 3.

[15] Muhammad Asif Khan, 2011. Total Quality Management and Organizational Performance-Moderating Role of Managerial Competencies. Journal of Business Research Vol 14.

[16] Bruce Han, Shaw K.Chen, Maling 2007. The Impact of ISO 9000 on TQM and Business Performance, International Journal of Production Research,23,415-431.

[17] Porter, Michael E. 2000. What is Strategy?. Harvard Business Review. November-December. Pp 61-78.

[18] Grant M.R 2002. Contemporary Strategy. Analysis : Concepts, Techniques, Aplication. $4^{\text {th }}$ edition. Blackwell Publisher Inc. Massachusetts. Grant (1995:164),

[19] Robbin,P.R and Timothy A Judge , 2008. Essentials of Organizational Behavior. $9^{\text {th }}$ Pearson Prentice Hall.

[20] Kim, Linsu \& Lim Y,2008. Environment Generic Strategies \& Performance in a Rapidly Developing Country. Academy of management Journal, Vol 13.

[21] Chow-Chua, et al.,2002).

[22] Flynn,B.B., Huo,B.and Zhao,X., 1992. The Impact of Supply Chain integration on Performance : a Contingency and Configuration Approach, Journal of Operations Management,28(1). 
[23] Kaplan, Robert S dan David P. Norton, 1996, Balanced Scorecard: Translating Strategy Into Action, Boston: Havard Business School Press.

[24] ........., 1992. The Balance Scorecard Measures That Drive Perfomance, Harvard Business Review, January-February 1992, pp. 71-79.

[25] ,........2004. Alignment: Using the Balanced Scorecard to Create Corporate Synergies. Harvard Business School.

[26] ...........2007. Using the Balanced Scorecard as a Strategic Management, Harvard Business Review, July -August, pp. 150 -161

[27] Solimun, Heungsun Hwang,Hec Montreal dan Yhoshio Takane ,2004. Pemodelan Struktural Generalized Structural Component Analysis GSCA. Diklat Fakultas MIPA Universitas Brawijaya Malang.

[28] Disperindag Jawa timur , 2010

[29] Henry Pribadi \& Kazuyori Kanai , 2011. Examining and Exploring Indonesian Small and Medium Enterprise Performance : An Empirical Study. . Journal of Management. Vol. 12.

[30] Child John.1997. Strategic Choice in the Analysis of Action, Structure,Organization and Environment : Retrospect and prospect. Organization Studies Vol 18.

[31] Lee J. \& Miller D. 2000. Strategy Environment \& Performance in Two Technological Contexts : Contingency Theory in Korea. Organizational Studies. Vol. 17 no.5. pp 729-750.

[32] Surachman Sumawihardja, 2002. Mengembangkan Keunggulan Bersaing Usaha Kecil Menengah Untuk Mencapai Posisi pasar yang Kuat dan Berkesimanbungan dalam Era Global. Makalah Kuliah Kenangan dan Apresiasi, UNPAD bandung.

[33] S.Bruce Han,Shaw K.Chen, Maling (2007)

[34] Clark T.Varadarajan P.R , Pride W.M.1994. Environmental Management : The Construct \& Research propositions. Journal of Business Research Vol 29.pp 143.

[35] Swamidas,P.M \& Newell,W.T,1987. Manufacturing Strategy, Environment Uncertainty and Performance : A Path Analitic Models. Management Science. Vol 33, No.4.

[36] Lau,S.M. 2002. Competitive Factors and Their Relative Importance in the US Electronics and Computer Industries. International Journal of Operations \& Product: Action management, Vol. 22. Pp 125-135.

[37] Luo Yadong, 1999. Environment-strategy-performance Relation in Small Business in China : A Case of Township \& Village Enterprises in Southern China. Journal of Business Management. January pp.37-52.

[38] Elenkov, Detelin S. 1997. Strategic Uncertainty \& Environmental Scanning : The Case for Instutional Influences on Scanning Behavior. Strategic Management Journal, Vo.18. pp : 287-302.

[39] Tan. Justin. 1996. Regulatory Environment and Strategic Orientations in Transitional Economy: A Study of Chinese Private Enterprise. Entrepreneurship Theory and Practice. Fall. Pp. 31-35.

[40] Tan. J.J. \& Litschert. R.J.. 1994. Environment Strategy Relationship and its Performance Implications : An Emperical Study of the Chinese Electronics Industry. Strategic Management Journal. Vol. 15. Pp. 1-20.

[41] Milliken, Frances J. 1997. Three Thpes of Perceived Uncertainty About the Environment : State, Effect \& Response Uncertainty Academy of Management Review. Vol 12.

[42] Irhas effendi, Muafi 2007. The Relationship Between Environment, Strategy, Organizational Structure, and Business Performance. Journal of Management. Vol. 53.

[43] Ibrahim Ingga. 2008, Pengaruh lingkungan Eksternal, Lingkungan Interna, Strategi Kepemimpinan Biaya, Strategi Diferensiasi, terhadap Nilai Pelanggan dan Keunggulan Bersaing, Disertasi Program Pascasarjana UB Malang.

Appendix I. Validity and Reliability test of measures ( Result SPSS)

\begin{tabular}{|c|c|c|c|c|c|}
\hline \multirow[t]{2}{*}{ Variables } & \multirow{2}{*}{$\begin{array}{c}\text { Research } \\
\text { Instrument }\end{array}$} & \multicolumn{2}{|c|}{$\begin{array}{c}\text { Validity Test } \\
\text { (Product Moment) }\end{array}$} & \multicolumn{2}{|c|}{$\begin{array}{c}\text { Realibility Test } \\
\text { (Chronbach's Alpha) }\end{array}$} \\
\hline & & Coefficient & & Coefficient & \\
\hline \multirow{9}{*}{$\begin{array}{c}\text { External } \\
\text { Business } \\
\text { Environment } \\
\quad\left(\mathrm{X}_{1}\right)\end{array}$} & $\mathrm{X}_{1.1 .1}$ & 0,397 & Valid & \multirow{9}{*}{0,892} & \multirow{9}{*}{ Reliable } \\
\hline & $\mathrm{X}_{1.1 .2}$ & 0,512 & Valid & & \\
\hline & $\mathrm{X}_{1.1 .3}$ & 0,479 & Valid & & \\
\hline & $\mathrm{X}_{1.1 .4}$ & 0,554 & Valid & & \\
\hline & $\mathrm{X}_{1.2 .1}$ & 0,721 & Valid & & \\
\hline & $\mathrm{X}_{1.2 .2}$ & 0,779 & Valid & & \\
\hline & $\mathrm{X}_{1.2 .3}$ & 0,728 & Valid & & \\
\hline & $\mathrm{X}_{1.2 .4}$ & 0,746 & Valid & & \\
\hline & $\mathrm{X}_{1.2 .5}$ & 0,397 & Valid & & \\
\hline \multirow{9}{*}{$\begin{array}{c}\text { TQM } \\
\text { Implementation } \\
\left(\mathrm{X}_{2}\right)\end{array}$} & $\mathrm{X}_{2.1 .1}$ & 0,553 & Valid & \multirow{9}{*}{0,904} & \multirow{9}{*}{ Reliable } \\
\hline & $\mathrm{X}_{2.1 .2}$ & 0,417 & Valid & & \\
\hline & $\mathrm{X}_{2.1 .3}$ & 0,440 & Valid & & \\
\hline & $\mathrm{X}_{2.2 .1}$ & 0,627 & Valid & & \\
\hline & $\mathrm{X}_{2.2 .2}$ & 0,301 & Valid & & \\
\hline & $\mathrm{X}_{2.2 .3}$ & 0,645 & Valid & & \\
\hline & $\mathrm{X}_{2.3 .1}$ & 0,881 & Valid & & \\
\hline & $\mathrm{X}_{2.3 .2}$ & 0,849 & Valid & & \\
\hline & $\mathrm{X}_{2.3 .3}$ & 0,773 & Valid & & \\
\hline \multirow[t]{4}{*}{ Variables } & \multirow{2}{*}{$\begin{array}{c}\text { Research } \\
\text { Instrument }\end{array}$} & \multicolumn{2}{|c|}{$\begin{array}{c}\text { Validity Test } \\
\text { (Product Moment) }\end{array}$} & \multicolumn{2}{|c|}{$\begin{array}{c}\text { Realibility Test } \\
\text { (Chronbach's Alpha) }\end{array}$} \\
\hline & & Coefficient & & Coefficient & \\
\hline & $\mathrm{Y}_{1.1 .1}$ & 0,392 & Valid & & \\
\hline & $\mathrm{Y}_{1.1 .2}$ & 0,353 & Valid & & \\
\hline
\end{tabular}




\begin{tabular}{|c|c|c|c|c|c|}
\hline \multirow{7}{*}{$\begin{array}{c}\text { Competitive } \\
\text { Strategy } \\
\left(\mathrm{Y}_{1}\right)\end{array}$} & $Y_{1.1 .3}$ & 0,573 & Valid & \multirow{7}{*}{0,904} & \multirow{7}{*}{ Reliable } \\
\hline & $Y_{1.2 .1}$ & 0,528 & Valid & & \\
\hline & $Y_{1.2 .2}$ & 0,561 & Valid & & \\
\hline & $Y_{1.2 .3}$ & 0,676 & Valid & & \\
\hline & $Y_{1.3 .1}$ & 0,787 & Valid & & \\
\hline & $Y_{1.3 .2}$ & 0,728 & Valid & & \\
\hline & $Y_{1.3 .3}$ & 0,751 & Valid & & \\
\hline \multirow{12}{*}{$\begin{array}{l}\text { Business } \\
\text { Performance } \\
\quad\left(\mathrm{Y}_{2}\right)\end{array}$} & $Y_{2.1 .1}$ & 0,659 & Valid & \multirow{12}{*}{0,907} & \multirow{12}{*}{ Reliable } \\
\hline & $Y_{2.1 .1 .2}$ & 0,342 & Valid & & \\
\hline & $Y_{2.1 .3}$ & 0,403 & Valid & & \\
\hline & $Y_{2.2 .1}$ & 0,309 & Valid & & \\
\hline & $Y_{2,22}$ & 0,465 & Valid & & \\
\hline & $Y_{2.2 .3}$ & 0,395 & Valid & & \\
\hline & $Y_{2.3 .1}$ & 0,389 & Valid & & \\
\hline & $Y_{2.3 .2}$ & 0,380 & Valid & & \\
\hline & $Y_{2.3 .3}$ & 0,435 & Valid & & \\
\hline & $Y_{2.4 .1}$ & 0,584 & Valid & & \\
\hline & $Y_{2.4 .2}$ & 0,823 & Valid & & \\
\hline & $Y_{2.43}$ & 0,771 & Valid & & \\
\hline
\end{tabular}

Appendix II. Data processing result GSCA

\begin{tabular}{|c|c|}
\hline \multicolumn{2}{|c|}{ Model Fit } \\
\hline FIT & 0.565 \\
\hline AFIT & 0.552 \\
\hline GFI & 0.974 \\
\hline SRMR & 0.097 \\
\hline NPAR & 29 \\
\hline
\end{tabular}

Measurement Model

\begin{tabular}{|c|c|c|c|c|c|c|c|c|c|}
\hline \multirow[t]{2}{*}{ Variable } & \multicolumn{3}{|c|}{ Loading } & \multicolumn{3}{|c|}{ Weight } & \multicolumn{3}{|c|}{ SMC } \\
\hline & Estimate & SE & $\mathbf{C R}$ & Estimate & SE & $\mathbf{C R}$ & Estimate & SE & $\mathbf{C R}$ \\
\hline $\begin{array}{l}\text { External Business } \\
\text { Environment }\end{array}$ & \multicolumn{9}{|c|}{ AVE $=0.636$, Alpha $=0.800$} \\
\hline $\mathrm{X} 11$ & 0.795 & 0.032 & $25.03^{*}$ & 0.625 & 0.032 & $19.75^{*}$ & 0.632 & 0.050 & $12.68^{*}$ \\
\hline $\mathrm{X} 12$ & 0.799 & 0.031 & $25.93^{*}$ & 0.630 & 0.032 & $19.66^{*}$ & 0.639 & 0.049 & $13.12^{*}$ \\
\hline $\begin{array}{c}\text { TQM } \\
\text { Implementation }\end{array}$ & \multicolumn{9}{|c|}{$\mathrm{AVE}=0.648$, Alpha $=0.727$} \\
\hline $\mathrm{X} 21$ & 0.828 & 0.034 & $24.69^{*}$ & 0.449 & 0.030 & $14.83^{*}$ & 0.685 & 0.054 & $12.68^{*}$ \\
\hline X22 & 0.777 & 0.053 & $14.52^{*}$ & 0.399 & 0.030 & $13.39^{*}$ & 0.603 & 0.078 & $7.7^{*}$ \\
\hline $\mathrm{X} 23$ & 0.809 & 0.033 & $24.6^{*}$ & 0.393 & 0.035 & $11.29^{*}$ & 0.654 & 0.053 & $12.27^{*}$ \\
\hline $\begin{array}{l}\text { Competitive } \\
\text { Strategy }\end{array}$ & \multicolumn{9}{|c|}{$\mathrm{AVE}=0.637$, Alpha $=0.712$} \\
\hline Y11 & 0.808 & 0.045 & $18.03^{*}$ & 0.402 & 0.034 & $11.81^{*}$ & 0.653 & 0.068 & $9.66^{*}$ \\
\hline Y12 & 0.902 & 0.018 & $49.43^{*}$ & 0.526 & 0.044 & $11.98^{*}$ & 0.813 & 0.033 & $24.9^{*}$ \\
\hline Y13 & 0.667 & 0.065 & $10.2^{*}$ & 0.301 & 0.041 & $7.42^{*}$ & 0.445 & 0.086 & $5.18^{*}$ \\
\hline $\begin{array}{c}\text { Business } \\
\text { Performance }\end{array}$ & \multicolumn{9}{|c|}{$\mathrm{AVE}=0.599$, Alpha $=0.767$} \\
\hline Y21 & 0.664 & 0.076 & $8.71^{*}$ & 0.408 & 0.069 & $5.92^{*}$ & 0.440 & 0.097 & $4.54^{*}$ \\
\hline Y22 & 0.675 & 0.136 & $4.95^{*}$ & 0.412 & 0.092 & $4.48^{*}$ & 0.456 & 0.150 & $3.04^{*}$ \\
\hline $\mathrm{Y} 23$ & 0.671 & 0.119 & $5.62^{*}$ & 0.363 & 0.080 & $4.53^{*}$ & 0.450 & 0.145 & $3.11^{*}$ \\
\hline Y24 & 0.539 & 0.125 & $4.31^{*}$ & 0.384 & 0.087 & $4.42^{*}$ & 0.291 & 0.131 & $2.22^{*}$ \\
\hline
\end{tabular}

$\mathrm{CR}^{*}=$ significant at .05 level 


\section{Structural Model}

\begin{tabular}{|c|c|c|c|}
\hline \multicolumn{4}{|c|}{ Path Coefficients } \\
\hline & Estimate & SE & $\mathbf{C R}$ \\
\hline External Business Environment -> Competitive Strategy & 0.214 & 0.071 & $3.0^{*}$ \\
\hline External Business Environment -> Business Performance & 0.057 & 0.125 & 0.45 \\
\hline TQM Implementation -> Competitive Strategy & 0.565 & 0.068 & $8.34^{*}$ \\
\hline TQM Implementation -> Business Performance & 0.074 & 0.143 & 0.52 \\
\hline Competitive Strategy -> Business Performance & 0.345 & 0.143 & $2.4^{*}$ \\
\hline
\end{tabular}

$$
\mathrm{CR}^{*}=\text { significant at } .05 \text { level }
$$

\begin{tabular}{|c|c|}
\hline \multicolumn{2}{|c|}{ R square of Latent Variable } \\
\hline External Business Environment & 0 \\
\hline TQM Implementation & 0 \\
\hline Competitive Strategy & 0.489 \\
\hline Business Performance & 0.186 \\
\hline
\end{tabular}

\begin{tabular}{|c|c|}
\hline \multicolumn{2}{|c|}{ Means Scores of Latent Variables } \\
\hline External Business Environment & 3.714 \\
\hline TQM Implementation & 3.740 \\
\hline Competitive Strategy & 3.876 \\
\hline Business Performance & 3.868 \\
\hline
\end{tabular}

\begin{tabular}{|c|c|c|c|c|}
\hline \multicolumn{5}{|c|}{ Correlations of Latent Variables (SE) } \\
\hline & $\begin{array}{c}\text { External Business } \\
\text { Environment }\end{array}$ & $\begin{array}{c}\text { TQM } \\
\text { Implementation }\end{array}$ & $\begin{array}{c}\text { Competitive } \\
\text { Strategy }\end{array}$ & $\begin{array}{c}\text { Business } \\
\text { Performance }\end{array}$ \\
\hline $\begin{array}{c}\text { External Business } \\
\text { Environment }\end{array}$ & 1 & $0.512(0.083)^{*}$ & $0.503(0.076)^{*}$ & $0.268(0.119)^{*}$ \\
\hline TQM Implementation & $0.512(0.083)^{*}$ & 1 & $0.675(0.057)^{*}$ & $0.336(0.103)^{*}$ \\
\hline Competitive Strategy & $0.503(0.076)^{*}$ & $0.675(0.057)^{*}$ & 1 & $0.423(0.080)^{*}$ \\
\hline Business Performance & $0.268(0.119)^{*}$ & $0.336(0.103)^{*}$ & $0.423(0.080)^{*}$ & 1 \\
\hline
\end{tabular}

* significant at .05 level 